\title{
The Trials and Triumphs of the Indian Schoolteachers During the Covid -19 Pandemic
}

\author{
Bishakha Bhattacharyya ${ }^{1^{*}} \quad$ Prachi Lahiri $^{2}$ \\ 1.National Public School, Indiranagar, HAL II Stage, $12^{\text {th }}$ A Main, Bangalore -560008 , India \\ 2.National Public School, HSR Layout, Sector 4, Bangalore - 560102, India \\ * E-mail of the corresponding author: bbishakha@npsinr.com
}

The authors did not receive any funding from any sources, whatsoever, for the research, authorship or publication of this research paper.

\section{Abstract}

The Covid-19 pandemic had a profound consequence on the traditional system of schooling. It underwent a complete transformation because of forced isolation, social distancing and closure of all physical schools. The ecology that used to support the school, namely the government, the parents and the society underwent a tumultuous time, each facing their own set of challenges. The Government policies had to be geared to meet the requirements of the pandemic and they kept changing frequently, the parents faced the anxiety of economic crisis, pay cuts and poor cash flow; the society saw deaths in unprecedented numbers. When the eco-system that supported the school was jarred, it had its ripple effect on the education system as well. This essay is focused on the impact the pandemic had on the psychological and financial well-being of the teachers and how they coped up with the situation and showed resilience to meet the challenges of the given crisis. It has been analysed in three stages -initial, middle and end of a year of online education as experienced by schoolteachers and Principals. It also highlights the learning and way forward from here. It has some useful suggestions for the policy makers and the school management.

Keywords: Covid-19, challenges, psychological and financial impact, teacher resilience, School principals

DOI: $10.7176 / \mathrm{JEP} / 12-15-04$

Publication date:May $31^{\text {st }} 2021$

\section{Introduction}

Nearly a billion and half students worldwide have faced disruption in their education due to the spread of Corona virus (UNESCO, 2021). The pandemic poses a massive challenge to the teachers to switch from face-to-face classroom education to online teaching and learning. The teachers undertook this challenge with the sole aim of ensuring continuity of education without compromising quality. What made this shift possible were the layers of changes and adjustments beneath it that included reorientation of teachers and their institutions, the students and their families. In this article, we will focus mainly on teachers. The viewpoints of the Principals have also been incorporated.

First, we explore the psychological and financial impact of the pandemic on the teacher community in India. We analyse the challenges faced by the teachers during the online classes and the methods they adopted to overcome the same. A section in the paper has been dedicated to school leaders/principals to understand this transition in its entirety.

In this article, we address some issues like the psychological and financial impacts of the pandemic on schoolteachers. We study the main challenges they faced during the online classes and discuss methods they undertook to overcome them. The role of the school management and principals in this transition has been analysed. Finally, we look at various ways to bring stability in the evolving education system and suggest ways to bring about a steady progress. Suggestions have been made from an insider's perspective as we are both schoolteachers in India.

\section{Literature Review}

In India on March 24, 2020, a complete lockdown was enforced to control the spread of the virus (BBC News, 2021). The schools were shut down indefinitely and teachers had no clue about the future. The first challenge for the teachers to overcome was being restrained within the four walls. This led to building of vicarious fear, as teachers were not really on the frontline to fight the pandemic. This symptom was largely seen in many professions across the world (Montemurro, 2020).

The size of the houses also mattered. In urban India, most middle class homes are small which does not give much room for all the members of the family to work simultaneously (Gopalan and Venkataraman, 2015). Given that the social status of teachers is low because of their limited earning potential as compared to other professions, the privileges given to them within a family is also limited (Aydin, Demir and Erdemli, 2015). Work from home was a novel concept and teachers had to adjust to it (Gautam and Sharma, 2020). Teachers had to adjust to new technology and help needed to upgrade their knowledge and technical knowhow was absent or at 
best limited (Joshi, Vinay and Bhaskar, 2020). The lack of adequate support in the entire ecosystem did not help in getting the teachers motivated to learn and adapt to the new challenges. There was paucity of funds and infrastructure for immediate upgrading of technology to support teaching from home. Online teaching needed good laptops and internet connectivity, which in many cases had to be shared by the entire family (ibid). All this created a sense of demotivation and frustration among the teachers.

The Government school teachers in India were impacted more than the private schools (Jain, Lall and Singh, 2020). Their students were in remote and difficult to reach places and that increased their challenges even further (ibid). India is a multi-lingual country but the e-learning platform is restricted to few languages (Mahapatra and Sarangi, 2020). Thus, it could not meet the demands of so many languages to cater to the needs of the vernacular mediums (Anitha and Nagalakshmi, 2021). The inequality in the availability of and access to education became stark. According to a survey by Ministry of Rural Development of India, it was found that only $47 \%$ of Indian households get power supply for more than 12 hours and 36\% schools do not have electricity supply at all (ibid) which highlights that the impediments that the teachers had to overcome to deliver the tutorials were extreme. Moreover, these socio-economical and infrastructural factors further widened the divide between the privileged and the underprivileged.

The readiness of teachers to work from home and deal with technology, largely depended on intrinsic factors like self-motivation and external factors like support from schools to upgrade the teacher's knowledge base (Scherer, Howard, Tondeur and Siddiq, 2021). In many cases, it was the first time that the teachers had to transition from in person teaching to online teaching and therefore the entire pedagogy had to be redefined and learnt from scratch. Teachers did not have the experience of gauging the understanding and grasp of the students on an online platform and some were not well versed in communication on the online mode (ibid). Where individuals had the hand-holding of institutions under good leadership, the outcomes were positive with successful transition towards online classes. Students learned better and teachers had a healthy mind-frame to take up the challenges of the pandemic (ibid). Evidence suggests that although teachers were inexperienced and totally unprepared for this drastic change, they were moderately keen to use various digital tools and willing to make online learning work (Gudmundsdottir and Hathaway, 2020).

Creativity is critical for effective teaching and learning process. It was creativity on the part of the teachers that acted as a major factor to overcome their challenges in the virtual classroom (Anderson, Bousselot, KatzBuoincontro and Todd, 2020). Through creative ways they were able to support the students, especially those who were marginalized. This proactive behaviour and growth mind-set of a few teachers had a positive impact on not only the students but also their fellow teachers. When the teachers got support from their institutions and they underwent training to master the required technology, their stress levels reduced considerably and were able to manage their situation better (ibid). The teachers could extend their help even in the lockdown period to the students. The online portal actually gave an avenue to bring out the creativity among some teachers and they could innovate new methods to develop and upgrade the pedagogy (ibid). The positive belief in oneself and a healthy self-image of the teachers translated to better results among students (Anderson and Haney, 2020).

\section{Ethical Considerations}

This study was conducted conforming to the code of conduct of research on human subjects in the country. The survey ensured the confidentiality and anonymity of the study participants. We wrote to our respective school Principals with the background of the research to seek their approval. After their approval, we shared out the same with an attached video to our respective teacher community groups which included our colleagues at school and other teacher groups in India.

The research participants were adults, and they were briefed about the aims of the project, a description of what will be required of the participants, a statement which addresses confidentiality and security of information (anonymous responses were collected), details of who will have access to personal information and the purpose(s) for which participant information will be used and a statement that participation in the research is completely voluntary. Since the responses were anonymous, it did not involve any potential risks, harms, and benefits to participants.

\section{Methods}

\subsection{Data Collection}

Data was collected through structured questionnaires administered to 401 teachers selected from India. The majority of the teachers resided to urban India. Interviews with open ended questions were conducted with seven teachers to understand their experiences in detail and obtain narratives of real life examples.

We sent out Google forms to different school-groups across India. Principals also shared their experience of the lockdown that ensued due to the pandemic. We received responses from 40 school principals. The majority of the principals were from urban India. 


\subsection{Data Analysis}

The analysis is based on challenges faced by teachers due to the pandemic. We looked into factors that increased the stress levels of teachers. Additionally we explored the elements that shaped the mindset of teachers to deal with the situation.

We also probed into the challenges faced by Principals and school leaders, the common online portals that were selected for online school education and the learning from the online teaching that could be carried forward.

Since we had the insider's perspective, we drafted questions based on our one year experience in online teaching. The questions were of multiple choice and the responses obtained were statistically analyzed by drawing a pie chart for better visual understanding. Two separate Google form questionnaires were administered to teachers and principals. The responses from the open ended Google form shared with the seven teachers were analyzed to investigate overlapping themes or evidence to support the emerging trends from the Google forms.

The findings from the teacher survey and individual teacher interviews along with the analysis are presented first, followed by the Principal survey observations and discussion.

\section{Results and Discussions}

\subsection{Teacher Survey and Individual Interviews}

The following are the results of the Teacher Survey Form conducted for 401 teachers and detailed interviews from seven teachers:

Psychological impact

In March 2020, post lockdown, what were your initial feelings?

401 responses

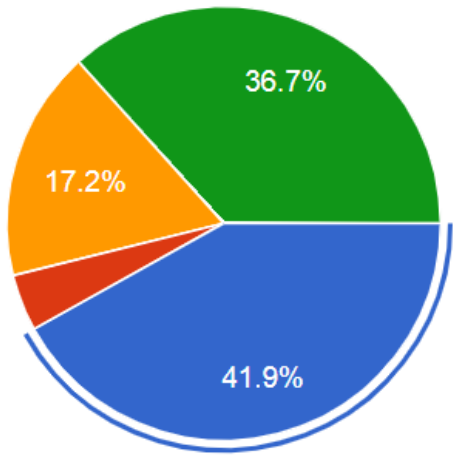

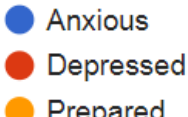

Prepared

Scared and uncertain

\section{Figure 1: Initial mental make-up of teachers}

This research attempts to highlight the transition the teachers underwent from March 2020, to March 2021. Based on the research done, 41.9\% (168 out of 401) of the teachers said, in March 2020, when the lockdown started, they felt anxious whereas, 36.7\% (147 out of 401) felt sad and uncertain of the situation (Figure 1). Our findings are in line with those of Rehman, Shahnawaz, Khan, Kharshiing, Khursheed, Gupta, Kashyap, and Uniyal (2021) whose research studied the stress and anxiety levels of different professions in India due to the pandemic. Teachers and academicians reported increased stress and anxiety levels when compared to those in other corporate jobs who reported normal stress levels. In the initial phase of the lockdown, teachers had to use online platforms that most of them may have never used before or were not competent with. In addition, online teaching was difficult due to insufficient internet bandwidth and other technological issues raising the anxiety levels in teachers.

This question was analysed in detail when we asked the teachers in the interview to describe the psychological impact of the work from home situation. Some of the challenges that they faced were to create a classroom environment at home, cancelling out noise and shutting out activities that are intrinsic to households (Joshi, Vinay and Bhaskar, 2020). Dealing with new technology caused stress. Others added that there were no defined timelines, and work life balance became very difficult (Kraft, Simon and Lyon, 2020). The next stumbling block was the loss of connection with the students on the online platform (Gautam and Sharma, 2020). The lack of face to face conversation resulted in boredom and the teachers lost motivation to teach (Baker, Peele, Daniels, Saybe, Whalen, Overstreet and The New Orleans, T.I.S.L.C., 2020). Another point that was highlighted was the stress accumulated through the day found vent on the family members, who bore the brunt of temper tantrums. The satisfaction derived in delivering the online class was not optimum (Aperribai, Cortabarria, Aguirre, Verche and Borges, 2020).These findings can be explained considering that shifting from traditional to online classroom was a radical and unplanned. 
What was the most difficult challenge to overcome?

401 responses

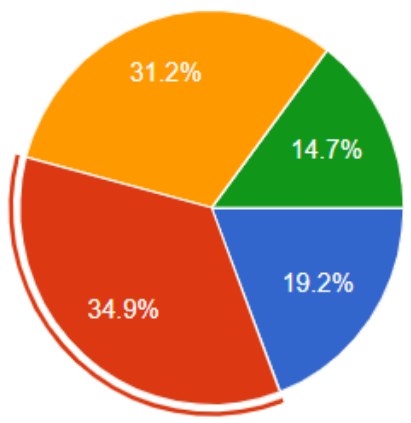

No domestic help

Lack of technological know-how

Social isolation

Financial constraint to upgrade einfrastructure

\section{Figure 2: Initial challenges}

Our studies support the fact that the most pressing concern among teachers $(34.9 \%$ or 140 out of 401 teachers) was the lack of technological know-how (Figure 2) Technical glitches caused the teacher to repeat the same instruction or topic many times which became tedious and boring. To learn new teaching tools and use them in the classroom without any glitch was an added stress (Obrad, 2020). Teachers from the rural areas complained that many of the students could not access the internet (Muthuprasad, Aiswarya, Aditya and Jha, 2021). Additionally, the teachers had to face a lot of technical glitches during classes (Raj and Khare, 2020). However, around $31.2 \%$ (125 out of 401) teachers said that social isolation was the most difficult challenge that they had to overcome. Peripheral problems like lack of domestic help added to their woes. Additionally, they faced financial constraints that prevented them from upgrading their e- infrastructure (Gautam and Sharma, 2020).

\section{Challenges faced in the online classroom}

What was the main challenge in online teaching?

401 responses

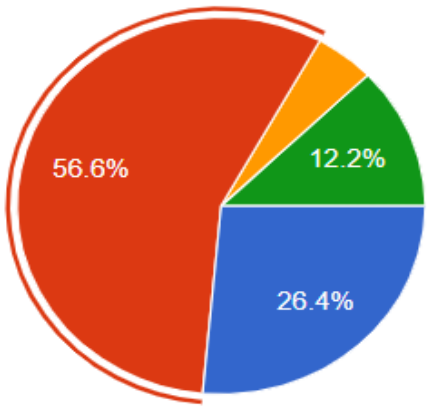

Internet bandwidth

Unresponsive students

Overenthusiastic students

Over-involvement of parents

\section{Figure 3: Challenges during online classes}

Referring to Figure $3,56.6 \%$ of the teachers (227 out of 401) highlighted the lack of response from students as the most bothering issue in the online classroom. This concern overshadowed all other challenging aspects. The teachers pointed out various factors like, absenteeism, unresponsive students and poor assessment tools aggravated the situation (Arora and Srinivasan, 2020.). Students were either not logging in or were not establishing any contact with the teachers (Santibañez and Guarino, 2021). Some teachers mentioned lack of interpersonal interaction and stifled student motivation as the most constraining factors (Alawamleh, Al-Twait, and Al-Saht, 2020).

In spite of the various deterrents in the online classroom, teachers were motivated (Obrad, 2020) and brought about various changes to alleviate the above mentioned problems. From the detailed interviews we learnt that some of the steps the teachers undertook included giving individual attention after class to unresponsive students, creating interactive sessions to engage the students, conducting remedial classes and charting intervention plans for weak students. Preparation and proper planning helped teachers to anticipate problematic situations beforehand (Kim, 2020). Teachers also employed different questioning techniques (Liu, 2019) and conducted activities to enliven the class. Student presentations were organized to get more student 
participation. Teachers also reported to have attended various technical trainings and conducted searches for apt online tools to enrich their teaching experience in the online class (Shenoy, Mahendra and Vijay, 2020).

When asked to list the challenges teachers faced due to the Government policies in their country to implement online classes, during the Covid-19 pandemic all of the seven participants in the interview had unique answers. While one participant had no issues with the government policies (Jena, 2020), others complained about lack of resources provided to conduct online classes, for example online tools like white-boards, material for experiments and technology for art integration in the syllabus. The third participant had to face disappointment due to constantly changing policies of the Government, which made implementation of school rules unstable (Bhat, Singh, Naik, Kamath, Mulimani and Kulkarni, 2020). The next participant pointed out that teaching hours were reduced therefore balancing between academic and non-academic classes became difficult which lowered the motivation of the students to join the classes and participate in only scholastic classes (ETGovernment.com. 2021). Thus, a combination of all these factors could have resulted in above normal stress levels.

Was any training provided by school management to upgrade e-skills?

401 responses

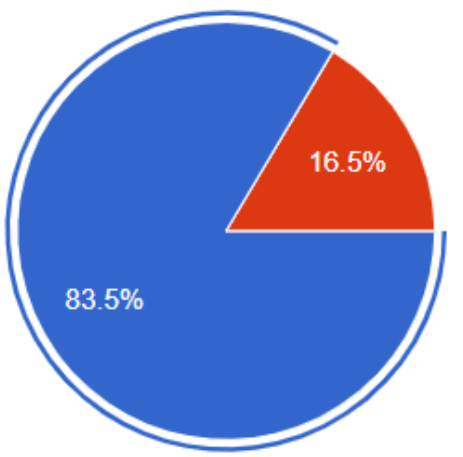

Yes

No

Figure 4: Training for upgrading e-skills

The World Bank's COVID-19 educational policy response is based on three principles of Coping, Managing Continuity followed by Improvement and Acceleration (Pubdocs.worldbank.org. 2021). Our study shows that $83.5 \%$ (335 out of 401) of the teachers were provided training by their schools to upgrade their skills (Shenoy, Mahendra and Vijay, 2020). It is heartening to see that most of the schools supported and trained their teachers for remote teaching as recommended by World Bank in Phase 1(Figure 4). Building digital skills to deliver distance learning was essential and most of the schools understood that and made rapid efforts to upgrade the skills of their teachers (ibid).

As a teacher, what was your major concern after lockdown?

401 responses

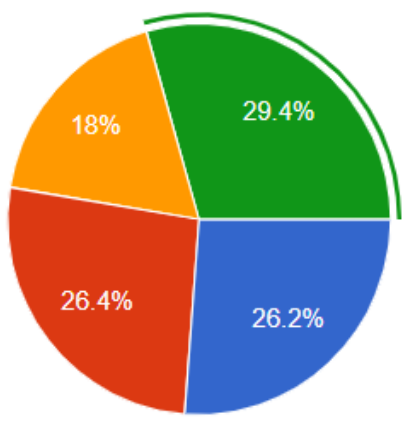

Health and safety of family and friends

Upgradation of infrastructure for online classes

Lack of technological know-how

Bonding with students

\section{Figure 5: Major concerns after lockdown}

Many teachers have reported that they had to put in greater effort to prepare for online classes and to design their lesson-plans to improve student interaction. Teachers tried to convert their students from passive learners to actively engaged learners through various online tools, presentations and open-ended discussions (Sun, Tang and 
Zuo, 2020, Poe, 2020). Initially, 29.4\% (118 out of 401) of the teachers felt establishing connect with the students on the digital platform could be challenging and felt that face to face courses were easier to establish personal connection (Glazier and Harris 2020). This concern was more disturbing for the teachers as compared to health and safety of family and friends. (Figure 5)

\section{Satisfaction levels of teachers}

How satisfied were you in delivering the subject content to your students on the online platform?

401 responses

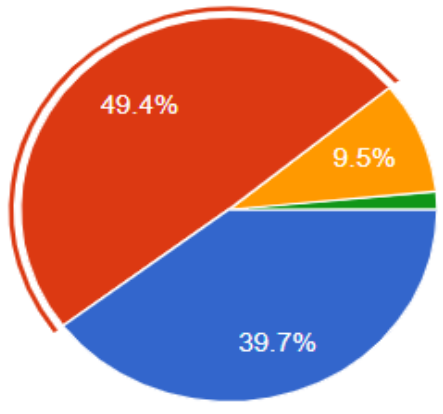

Very satisfied

Somewhat satisfied

Somewhat dissatisfied

Very dissatisfied

\section{Figure 6: Satisfaction levels in delivering subject content online}

However, when asked whether they were satisfied with delivering the subject content on the online platform $39.7 \%$ (159 out of 401) reported they were very satisfied while 49.4\% (198 out of 401) said they were somewhat satisfied (Figure 6).

How successful were you as a teacher to emotionally bond with your students on the online platform?

401 responses

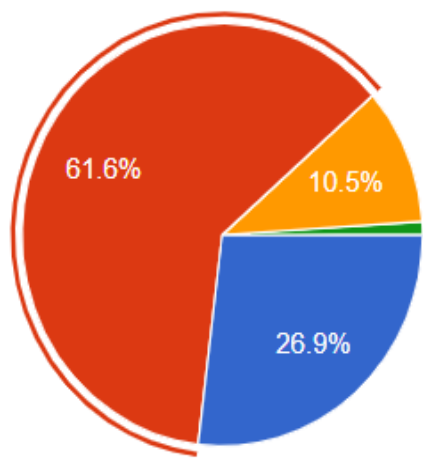

Very successful

Somewhat successful

Somewhat unsuccessful

Very unsuccessful

\section{Figure 7: Level of emotional bonding of students}

On being asked whether they were successful in emotionally bonding with students, close to $27 \%$ (108 out of 401) said they were very successful, while $61.6 \%$ (247 out of 401) said they were somewhat successful, which shows that a clear majority of teachers were satisfied with establishing a bond with the students (Figure 7). We can infer that stronger teacher-student bond resulted in better academic engagement leading to higher levels of satisfaction for the teachers (Zaccoletti, Camacho, Correia, Aguiar, Mason, Alves and Daniel, 2020). 


\section{Financial Impact}

By what percentage was your salary reduced post-lockdown?

401 responses

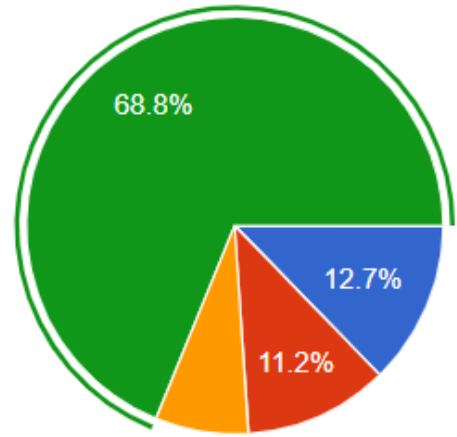

$10 \%$ to $30 \%$

$30 \%$ to $50 \%$

more than $50 \%$

was not reduced at all

\section{Figure 8: Financial impact}

A shocking revelation that came about through this survey was the immense financial pressure faced by teachers in India. In the survey conducted, while $68.8 \%$ (276 out of 401$)$ of the teachers reported no salary cuts, around $12.7 \%$ reported a $10-30 \%$ salary cut, $11.2 \%$ (45 out of 401$)$ reported a $30-50 \%$ cut and around $7.2 \%(29$ out of 401 ) reported greater than $50 \%$ cut in their salaries (Figure 8). In the interviews conducted however, many teachers reported huge cuts in their salaries and most of them showed the disappointment of being overworked and underpaid. Onyema, Eucheria, Obafemi, Sen, Atonye, Sharma and Alsayed (2020) have reported job losses and increased debts as one of the impacts of Coronavirus pandemic on the education sector. There was a fear among the teachers of being laid off along with widespread salary cuts and majority of teachers reported more than $50 \%$ cuts in their take- home packages (Khanna and Kareem, 2021). During the lockdown, close to 40,000 private school teachers lost their jobs in the state of Karnataka, in India (Deccan Chronicle, 2021). Although budget schools complained about parents not depositing fees last year, there were a few premium schools that reduced teacher salaries by $30-50 \%$ (ibid). The states of Haryana and Maharashtra too reported roughly 60,000 teachers who lost their jobs as reported in various articles of the leading daily, Times of India (2021a, 2021b). The inability to pay a teacher his/her due is something that should be looked into seriously and with urgency.

Another point that could be highlighted here is that most of the private schools teachers get paid a fraction of what the government schools pay (Kingdon, 2020. The private schools generally pay a salary influenced by the demand and supply of educated teachers in the labour market unlike government schools, where the pay could be influenced by political currents or teacher union lobbies. Private schools take advantage of the excess supply of educated graduates willing to take up teaching jobs (ibid). Interestingly, government school teachers did not report salary cuts while, the majority of salary cuts came from private schools. This fact emerged through the personal interviews that were taken. In the interview, when teachers were asked what were the financial implications they faced due to the closure of schools during the pandemic the answers were not so varied. Only two among seven participants said that there was no impact of the pandemic on their financial situation. The rest said that they faced either salary cuts or they did not get any annual raise (Bokde, Kharbikar, Roy, Joshi and Ga, 2020). One teacher said that the schools expected them to go on school duty with no school buses plying and the expenses had to be borne by the teachers. There were pay cuts on top of it and they were supposed to upgrade their electronic infrastructure with no institutional aid. Another teacher said that there was a pay cut of sixty percent and they were unable to take care of the basic personal commitments, for as long as four months. One teacher also said that though the take-home amount reduced, the workload increased tremendously because they had to completely transform the way they taught, which in turn resulted in frustration and despair (Khanna and Kareem, 2021). 


\section{The way forward for online education}

In which areas do you think the online portal should continue, even after returning to offline regular school?

401 responses

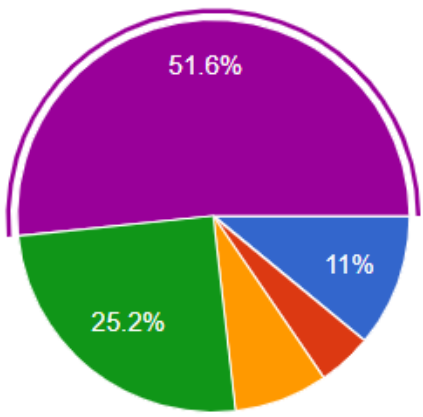

Parent teacher meetings

Management-teacher meetings

Remedial classes

Uploading homework and assignment

All of the above

\section{Figure 9: Aiming for continuity}

Going forward, majority of the teachers $(51.6 \%$ or 207 out of 401$)$ felt that the online platform could be continued for conducting meetings (parent teacher and management-faculty), uploading of homework and for remedial classes (Figure 9). This view was bolstered by the teachers in their personal interview as they said that post COVID, a blended approach should be undertaken where the best practices of online and physical classrooms should be adopted. The value of human interaction can never be undermined (Chellathurai, 2020). However there has been a paradigm shift in how online education was perceived earlier (Dhawan, 2020)

\section{After one year of online teaching: Teachers' emotions}

After one year of online teaching, which statement would describe you best?

401 responses

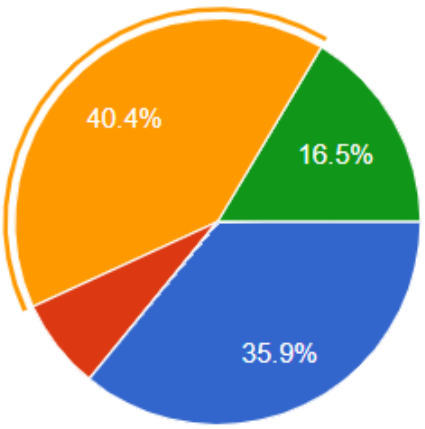

Bring it on!!

Broken and tired

Feeling enlightened

Want to break free

\section{Figure 10: Emotions after one year of online teaching}

When asked how the teachers felt after a year of teaching online, more than $75 \%$ of the teachers said they feel enlightened and are ready to face further challenges and only a small fraction (7.2\%) said they feel broken and tired (Figure 10). With such resilient and motivated teachers, we can only be assured that the future of the younger generation is in safe and strong hands. Based on the in depth and genuine interview responses from the teachers, it was revealed that it is possible to have effective teaching even on the online platform. Teachers also said that developing a bond and connection with students is possible even across the screen. However, few teachers felt that nothing could replace face to face interaction (Fauzi and Khusuma, 2020). Up-skilling oneself and to be abreast with the latest technological changes, to be future ready was unanimously agreed upon.

\subsection{Principal/School Leader Survey}

The following are the results of the Principal Survey Form conducted for 40 Principals: 
As a school leader, what was your main challenge in shifting to the online mode?

40 responses

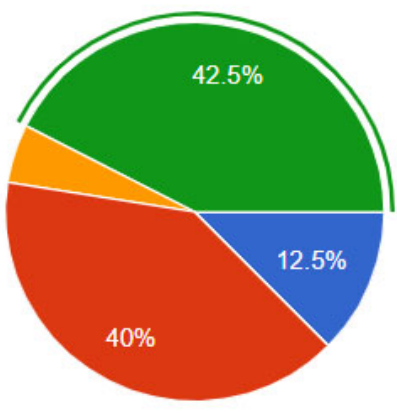

Motivating teachers

Convincing parents of quality education on an online set-up

Dealing with Government policies

Providing e-platform and relevant training to the teachers

\section{Figure 11: Challenges while shifting to the online mode}

How would you rate the resilience and adaptability of the faculty members?

40 responses

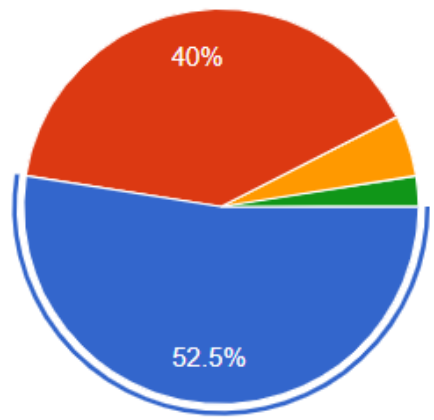

Very high

Somewhat high

Low

Very Low

\section{Figure 12: Resilience levels of faculty}

Challenges faced by Principals while shifting to the online mode and Resilience levels of faculty

On the onset of the lockdown, 17 out of 40 Principals or nearly $42.5 \%$, felt that providing the necessary training to the teachers and arranging the e-platform through which education could be imparted was the most difficult challenge (Figure 11). Since most of the teachers were either not technologically savvy or had not been exposed to such educational tools, the teachers also had mental blocks that they needed to overcome (Kulikowski, Przytuła and Sułkowski, 2021). Teachers were reluctant to learn all the different pedagogical online tools which were expected of them on a war footing. In very little time they had to adapt and modify themselves (ibid). However, only $12.5 \%$ (only 5 out of 40 ) of the Principals found motivating teachers to accept the new technology as a difficult task. This shows that teachers were resilient and adapted themselves to the new situation and accepted the new learning. High resilience of the teachers to accept the new set-up has been applauded by more than $90 \%$ of the Principals (Figure 12). Only 5\% said it was low and 2.5 percent said that it was very low (Rahayu, Altaftazani, Kelana, Firdaus and Fauzi, 2020). 
Was any professional training provided for the teachers during the lockdown?

40 responses

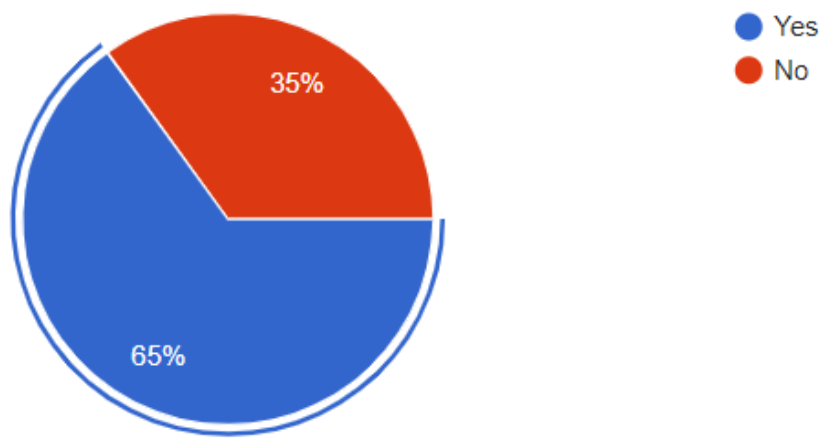

Figure 13: Provision of professional training

According to the survey, almost $65 \%$ of the Principals were able to provide the much needed technological support and training to the teachers that were needed to shift to the online class set-up (Figure 13). Unfortunately, $35 \%$ of them had to fend for themselves with no guidance or training.

\section{Challenges faced by Principals posed by parents}

Another exacting challenge the principals faced was convincing the parents about the quality of education that would be imparted to the students (Figure 11) The parents had their own set of beliefs and since they are very important stake-holders of the education system, their feedback and alignment meant a lot (Garbe, Ogurlu, Logan and Cook, 2020). Parents readily agreed to complete lockdown because it had direct impact on the health of their family. However, since they were themselves juggling between maintaining a balance between their office work and household chores, the added burden of the child's education was yet another strain. They also were not sure how to motivate their own children and gauge the learning outcome (ibid). 16 out of 40 or $40 \%$ of the Principals validated that convincing the parents, bringing them onboard and assuring them of quality online education was challenging.

Which area was worst affected by the lockdown?

40 responses

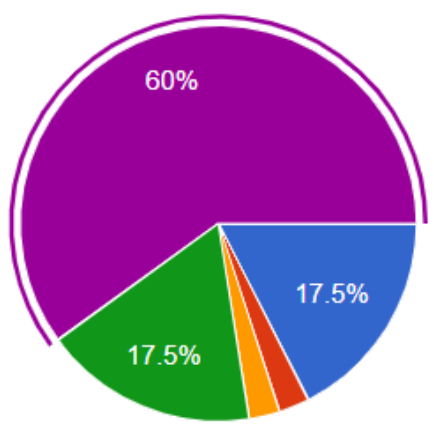

Admission of new students

Hiring of new teachers

Retaining old teachers

Rolling out pay-cuts

Getting parents' compliance regarding tuition fee payment

\section{Figure 14: Areas worst affected in smooth running of school}

Parents' refusal to pay the school fee when the schools were shut down during Covid had the biggest impact on the schools. $60 \%$ of the Principals had labeled it as an insurmountable task (Figure 14). This trend was noticed not only in India but also in other countries like South Africa and it had a direct impact on the budget and finances of the schools (du Plessis, 2020). This non-compliance to fee payment had a snowball effect where the schools failed to upgrade the teachers with better facilities to take online classes and give them technological know-how which was much needed to ease the shift from regular classes to online classes (Joshi, Vinay and Bhaskar, 2020). The survey shows that $17.5 \%$ of the Principals found it very difficult to announce pay cuts to the teachers, which was a ripple effect of the paucity of funds faced by the schools. Another $17.5 \%$ of principals in the survey, found it difficult to get new students to take admission in the academic year because of the closing of the physical schools (Bokde, Kharbikar, Roy, Joshi and Ga, 2020). Retaining old teachers and hiring new teachers was the least of the problem for the Principals as only 5\% of them faced these two issues collectively. 
This goes on to show that the mobility of the teachers regarding changing jobs was severely impaired during the lockdown even though they had to face financial problems. Similar findings have been highlighted in the analysis of the teacher's survey.

\section{Online portals used for e-learning}

What portal did your school use for e-learning?

40 responses

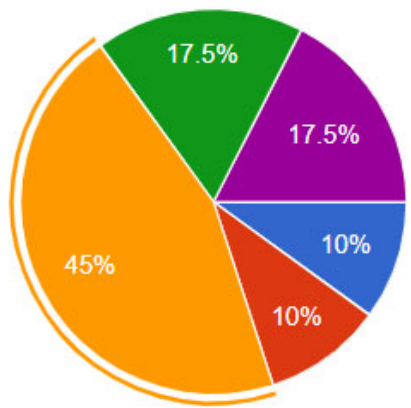

Government portals

Google Classrooms

Zoom

Microsoft Teams

Any other

\section{Figure 15: Most used online portal}

$45 \%$ of the Principals opted for Zoom online portal. Zoom was the dominant of all the portals. The next choice was Microsoft Teams with $17.5 \%$, Google and Government portals were the choice of $10 \%$ of the Principals each (Figure 15). Only $17.5 \%$ went with portals that were outside the ambit of the above. The students had negative perception about Zoom but they did appreciate the flexibility that it offered (Serhan, 2020). Students did like the recording facilities in Zoom that were available for thirty days. The classes could be downloaded, shared and stored on cloud. All these novel functionalities were welcomed (ibid). However, as the number of users increased in Zoom, security issues cropped up and students' interest started wearing down (ibid).

Microsoft Teams is highly rated as an educational tool and builds collaborative learning, social constructivism and the 'assignment' feature enhances multi-faceted ways of formative assessments (Martin and Tapp, 2019). However, Microsoft Teams which emerged next in popularity among the school leaders in the survey occupied less than half the market share taken by Zoom.

\section{Way forward for online education}

What features of the online classes would you like to retain even after regular offline school resumes?

40 responses

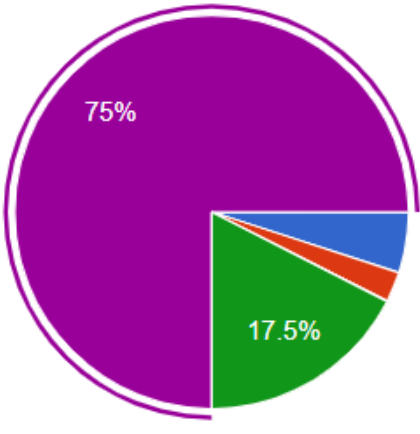

Parent teacher meetings

Management and teacher meetings

Remedial classes

Uploading homework and assignments of the students

All the above

\section{Figure 16: Principals aiming for continuity}

As seen in the teacher survey (Figure 9), $75 \%$ of the Principals (30 out of 40 ) also felt that the online portal could be effectively used in various ways even after face to face classes resume (Figure 16). The learning during online classes should definitely be carried forward in physical school scenario.

Based on the above analysis, we arrived at possible ways to improve and sustain online education in Indian schools. 


\section{Suggestion for policy makers and school management}

1. Access to internet and supporting infrastructure should be made available to the remotest corner of the country. This should be one of the topmost priorities of the government in order to facilitate learning for all and close the digital divide between haves and have-nots.

2. All teachers should be provided with appropriate (basic or advanced) training skills to continue teaching on the online platform.

3. The online portals should be continued even after face-to-face sessions resume in various ways as highlighted in the 'Discussions' section.

4. Parents should be made abreast of the trainings being provided by the school and other up-skilling in infrastructure that are being done via newsletters or school websites. This will help parents to appreciate the efforts being put in by the school authorities and hopefully majority of the parents will understand the implication of non-payment of fees.

5. School management should give due importance to the mental health of its employees. Counselling cells should be set up that are accessible by the faculty at all times. Tie ups with NGOs that promote mental welfare could be a good option to consider.

6. Pending salaries should be immediately disbursed from the school funds and further salary cuts should be avoided at all costs. Government assistance and financial relief via direct cash transfer or waiver of taxes should be extended to the education sector.

7. Alternate assessment techniques should be incorporated which focus on student participation and more weightage should be given to routinely held formative assessments. This will address one of the major concerns faced by the teacher regarding unresponsive students in the online classroom.

\section{Conclusion}

Through the COVID-19 situation, many challenges and opportunities have emerged in the education sector. We saw rapid digitalization of the education sector at a scale that was unprecedented (Maqsood, Abbas, Rehman and Mubeen, 2021). This change brought about the most widespread educational reform ever. Initially, the change was upsetting for teachers and students alike but after one year, it can be said that all the stake holders of education have gradually become comfortable with the online platform and have started to appreciate its usage and benefits too (Rizun and Strzelecki, 2020). Change leads to experiments and innovations. This change saw the teachers make a special effort that displayed their resilience and adaptability. Not only were new educational skills learnt but also life skills were acquired which involved sharing best practices amongst colleagues and putting a collaborative effort.

Digital education is here to stay in varied ways and teachers have to be provided with continuous and comprehensive training and support (Jena, 2020). No child should be left behind in this massive revamping of the education sector. Sharing of knowledge and best practices and prudent use of creative pedagogical tools and techniques will help teachers to enrich the digital learning environment and meet the learning requirements of the next generation of 'digital natives' (ibid).

\section{Limitations}

Medium sample size and dominating presence of teachers from English medium private schools of Tier 1 cities in India are seen as some of the limitations of the research. This restricts the generalisation of results. Secondly, the authors used online Google forms for data collection. Therefore, participation from teachers not having internet facilities or the underprivileged was not possible.

This research is an insider's perspective since both the authors are working as schoolteachers in urban India.

Future researchers should increase the sample size and reach out to teachers belonging to Tier2 and Tier3 cities and rural areas. A comparative study between the situations of teachers from government schools and private schools should be researched upon for a comprehensive understanding of the trials of the teachers in all segments of India. Analyzing the opinions of teachers from rural schools with less access to the latest technologies will give a better insight.

\section{Acknowledgement}

The authors would like to extend their deepest gratitude to all the teachers who participated in the survey for this study.

\section{Declaration of competing interest}

We declare that we do not have any personal or financial gains that could have impacted our research findings.

\section{Contributors}

Both the authors contributed equally. 


\section{Funding statement}

The authors did not receive any funding from any sources, whatsoever, for the research, authorship or publication of this research paper.

\section{Declaration of Conflicting Interests}

The authors declared no potential conflicts of interest with respect to the research, authorship and/or publication of this article.

\section{References}

1. Alawamleh, M., Al-Twait, L.M. and Al-Saht, G.R. (2020) The effect of online learning on communication between instructors and students during Covid-19 pandemic. Asian Education and Development Studies.

2. Anderson, R.C., Bousselot, T., Katz-Buoincontro, J. and Todd, J. (2020) Generating buoyancy in a sea of uncertainty: Teachers creativity and well-being during the COVID-19 Pandemic. Frontiers in psychology 11.

3. Anderson, R. C. and Haney, M. (2020) Reflection in the creative process of early adolescents: The mediating roles of creative metacognition, self-efficacy, and self-concept. Psychology of Aesthetics, Creativity, and the Arts.

4. Anitha, M.G. and Nagalakshmi, M. (2021) A changing education imperative in rural India during covid19. European Journal of Molecular \& Clinical Medicine 7(10): pp.3423-3431.

5. Aperribai, L., Cortabarria, L., Aguirre, T., Verche, E. and Borges, Á. (2020) Teacher's physical activity and mental health during lockdown due to the COVID-2019 Pandemic. Frontiers in Psychology 11: pp.2673.

6. Arora, A.K. and Srinivasan, R. (2020) Impact of pandemic COVID-19 on the teaching-learning process: A study of higher education teachers. Prabandhan: Indian journal of management 13(4): pp.43-56.

7. Aydin, I., Demir, T.G. and Erdemli, O. (2015) Teacher's views regarding the social status of the teaching profession. The Anthropologist 22(2): pp.146-156.

8. Baker, C.N., Peele, H., Daniels, M., Saybe, M., Whalen, K., Overstreet, S. and The New Orleans, T.I.S.L.C. (2020) The Experience of COVID-19 and Its Impact on Teachers' Mental Health, Coping, and Teaching. School Psychology Review pp.1-14.

9. BBC News. 2021. Teachers 'have worked long hours for many years'. [online] Available at: $<$ https://www.bbc.com/news/education-49728831> [Accessed 14 April 2021].

10. Bhat, R., Singh, V.K., Naik, N., Kamath, C.R., Mulimani, P. and Kulkarni, N. (2020) COVID 2019 outbreak: The disappointment in Indian teachers. Asian journal of psychiatry 50: pp.102047.

11. Bokde, V., Kharbikar, H.L., Roy, M.L., Joshi, P. and Ga, A. (2020) Possible impacts of COVID-19 pandemic and lockdown on education sector in India. Food and scientific reports pp.1-7.

12. Chellathurai, D.K.G.J. (2020) Future of Education Post Pandemic COVID-19: Online VS Classroom Learning-Redefining Education. International Research Journal.

13. Deccan Chronicle. 2021. Karnataka: Over 40,000 private school teachers lose job amid coronavirus crisis. [online] Available at: <https://www.deccanchronicle.com/nation/current-affairs/080720/karnataka-over40000-private-school-teachers-lose-job-amid-coronavir.html> [Accessed 13 April 2021].

14. Dhawan, S. (2020) Online learning: A panacea in the time of COVID-19 crisis. Journal of Educational Technology Systems 49(1): pp.5-22.

15. du Plessis, P. (2020) Implications of COVID-19 on the Management of School Financial Resources in Quintile 5 Public Schools. South African Journal of Education 40(4): pp.2043.

16. ETGovernment.com. 2021. COVID-19 Pandemic: Impact and strategies for education sector in India - ET Government. [online] Available $<$ https:/government.economictimes.indiatimes.com/news/education/covid-19-pandemic-impact-andstrategies-for-education-sector-in-india/75173099> [Accessed 6 April 2021].

17. Fauzi, I. and Khusuma, I.H.S. (2020) Teachers' elementary school in online learning of COVID-19 pandemic conditions. Jurnal Iqra': Kajian Ilmu Pendidikan 5(1): pp.58-70.

18. Garbe, A., Ogurlu, U., Logan, N. and Cook, P. (2020) Parents' experiences with remote education during COVID-19 school closures. American Journal of Qualitative Research 4(3): pp.45-65.

19. Gautam, R. and Sharma, M. (2020) 2019-nCoV pandemic: A disruptive and stressful atmosphere for Indian academic fraternity. Brain, behavior, and immunity.

20. Glazier, R. and Harris, H.S. (2020) Common traits of the best online and face-to-face classes: Evidence from student surveys. Political Science Education and the Profession

21. Gopalan, K. and Venkataraman, M. (2015) Affordable housing: Policy and practice in India. IIMB Management Review 27(2): pp.129-140.

22. Gudmundsdottir, G.B. and Hathaway, D.M.( 2020) "We Always Make It Work": Teachers' Agency in the Time of Crisis. Journal of Technology and Teacher Education 28(2): pp.239-250. 
23. Jain, S., Lall, M. and Singh, A. (2021) Teachers' voices on the impact of COVID-19 on school education: Are ed-tech companies really the panacea? Contemporary Education Dialogue 18(1): pp.58-89.

24. Jena, P.K. (2020) Impact of pandemic COVID-19 on education in India. International Journal of Current Research (IJCR) 12.

25. Joshi, A., Vinay, M. and Bhaskar, P. (2020) Impact of coronavirus pandemic on the Indian education sector: perspectives of teachers on online teaching and assessments. Interactive Technology and Smart Education.

26. Khanna, R. and Kareem, J. (2021) Creating inclusive spaces in virtual classroom sessions during the COVID pandemic: An exploratory study of primary class teachers in India. International Journal of Educational Research Open 2: pp.100038.

27. Kim, J. (2020) Learning and teaching online during Covid-19: Experiences of student teachers in an early childhood education practicum. International Journal of Early Childhood 52(2): pp.145-158

28. Kingdon, G.G. (2020) The private schooling phenomenon in India: A review. The Journal of Development Studies 56(10): pp.1795-1817.

29. Kraft, M.A., Simon, N.S. and Lyon, M.A. (2020) Sustaining a Sense of Success: The Importance of Teacher Working Conditions during the COVID-19 Pandemic. EdWorkingPaper No. 20-279. Annenberg Institute for School Reform at Brown University.

30. Kulikowski, K., Przytuła, S. and Sułkowski, Ł. (2021) E-learning? Never again! On the unintended consequences of COVID-19 forced e-learning on academic teacher motivational job characteristics. Higher Education Quarterly.

31. Liu, Y. (2019) Using reflections and questioning to engage and challenge online graduate learners in education. Research and Practice in Technology Enhanced Learning 14(1): pp.1-10.

32. Mahapatra, S. and Sarangi, I. (2020) Santhali Language in the Digital Media Space. Journal of Critical Reviews, 7(15), pp.2288-2297.

33. Martin, L. and Tapp, D. (2019) Teaching with Teams: An introduction to teaching an undergraduate law module using Microsoft Teams. Innovative Practice in Higher Education 3(3).

34. Maqsood, A., Abbas, J., Rehman, G. and Mubeen, R. (2021) The paradigm shift for educational system continuance in the advent of COVID-19 pandemic: Mental health challenges and reflections. Current Research in Behavioral Sciences 2: pp.100011.

35. Montemurro, N. (2020) The emotional impact of COVID-19: From medical staff to common people. Brain, behavior, and immunity.

36. Muthuprasad, T., Aiswarya, S., Aditya, K.S. and Jha, G.K. (2021) Students' perception and preference for online education in India during COVID-19 pandemic. Social Sciences \& Humanities Open 3(1): pp. 100101.

37. News, C., News, g., \& Haryana: One lakh teachers and non-teaching staff lost jobs after lockdown, s. (2021). Haryana: One lakh teachers and non-teaching staff lost jobs after lockdown, says survey | Gurgaon News - Times of India. The Times of India. Retrieved 4 May 2021, from https:/timesofindia.indiatimes.com/city/gurgaon/1-lakh-teachers-and-non-teaching-staff-lost-jobs-afterlockdown-says-survey/articleshow/76863917.cms.

38. News, C., News, n., \& Associations, O. (2021). Over 60k teachers have lost their jobs in state: Associations | Nagpur News - Times of India. The Times of India. Retrieved 4 May 2021, from https://timesofindia.indiatimes.com/city/nagpur/over-60k-teachers-have-lost-their-jobs-in-stateassociations/articleshow/77684276.cms.

39. Obrad, C. (2020) Constraints and Consequences of Online Teaching. Sustainability 12(17): pp.6982.

40. Onyema, E.M., Eucheria, N.C., Obafemi, F.A., Sen, S., Atonye, F.G., Sharma, A. and Alsayed, A.O. (2020) Impact of Coronavirus pandemic on education. Journal of Education and Practice 11(13): pp.108-121.

41. Poe, C.P. (2020) Pedagogy in the time of COVID-19. Croatian medical journal 61(3): pp.211.

42. Pubdocs.worldbank.org. (2021) [online] Available at: $<$ http://pubdocs.worldbank.org/en/487971608326640355/External-WB-EDU-Response-to-COVIDDec15FINAL.pdf $>$ [Accessed 13 April 2021].

43. Rahayu, G.D.S., Altaftazani, D.H., Kelana, J.B., Firdaus, A.R. and Fauzi, M.R. (2020) October. Analysis of elementary school students' mathematical resilience during learning during the covid 19 Pandemic. In Journal of Physics: Conference Series 1657(1): pp. 012001.

44. Raj, U. and Khare, S. (2020) Indian Education System in Fight against COVID-19 Pandemic. The impact of COVID19 on the international education system. Published: November 19th.

45. Rehman, U., Shahnawaz, M.G., Khan, N.H., Kharshiing, K.D., Khursheed, M., Gupta, K., Kashyap, D. and Uniyal, R. (2021) Depression, anxiety and stress among Indians in times of Covid-19 lockdown. Community mental health journal 57(1): pp.42-48.

46. Rizun, M. and Strzelecki, A. (2020) Students' acceptance of the Covid-19 impact on shifting higher education to distance learning in Poland. International Journal of Environmental Research and Public 
Health 17(18): pp.6468.

47. Santibañez, L. and Guarino, C.M. (2021) The Effects of Absenteeism on Academic and Social-Emotional Outcomes: Lessons for COVID-19. Educational Researcher p.0013189X21994488

48. Scherer, R., Howard, S.K., Tondeur, J. and Siddiq, F. (2021) Profiling teachers' readiness for online teaching and learning in higher education: Who's ready?. Computers in Human Behavior 118: pp.106675.

49. Serhan, D. (2020) Transitioning from Face-to-Face to Remote Learning: Students' Attitudes and Perceptions of Using Zoom during COVID-19 Pandemic. International Journal of Technology in Education and Science 4(4): pp.335-342.

50. Shenoy, V., Mahendra, S. and Vijay, N. (2020) COVID 19 lockdown technology adaption, teaching, learning, students engagement and faculty experience. Mukt Shabd Journal 9(4): pp.698-702.

51. Sun, L., Tang, Y. and Zuo, W. (2020) Coronavirus pushes education online. Nature Materials 19(6): pp.687-687.

52. Education: From disruption to recovery. UNESCO. (2021). Retrieved 4 May 2021, from https://en.unesco.org/covid19/educationresponse.

53. Zaccoletti, S., Camacho, A., Correia, N., Aguiar, C., Mason, L., Alves, R.A. and Daniel, J.R. (2020) Parents' Perceptions of Student Academic Motivation During the COVID-19 Lockdown: A Cross-Country Comparison. Frontiers in psychology 11. 